\title{
NEGATIVE MYOCARDIAL EFFECTS OF CYCLIC GMP ARE ENHANCED IN OBESE RATS
}

James Tse PhD, MD, Harvey R. Weiss PhD, Elizabeth Katz, MS, and Peter M. Scholz MD

Departments of Anesthesia, Physiology \& Biophysics and Surgery, UMDNJ-Robert Wood Johnson Medical School, New Brunswick, NJ 08901, USA

INTRODUCTION: It has been shown that lack of leptin, a regulator of food intake or leptin resistance lead to obesity ${ }^{1}$. In leptin defiant mice, functional decrements in isolated ventricular myocytes caused by cyclic GMP (cGMP) are greatly increased ${ }^{2}$. We tested the hypothesis that the negative myocardial responses to cGMP would be enhanced in leptin-resistant obese rats.

METHODS: Experiments were performed in anesthetized open chest 16 male Zucker obese rats and 13 age-matched control rats after ICACUC approval. Arterial blood gases, heart rates and blood pressures were obtained after stabilization and 15 min after applying either vehicle (saline) or 8 -Br-cGMP $(1 \mathrm{mM})$ topically to the left ventricular surface. Coronary blood flow $\left({ }^{141}\right.$ Ce-labeled microspheres) and $\mathrm{O}_{2}$ extraction (microspectrophotometry) measurements were used to determined myocardial $\mathrm{O}_{2}$ consumption $\left(\mathrm{VO}_{2}\right)$. Protein phosphorylation by cGMP protein kinase (protein electrophoresis) and low Km cAMP phosphodiesterase (A-PDE) (total and cGMP-inhibited) activities were also determined. ANOVA was used for statistical analysis. A value of $p<0.05$ was accepted as significant. Data were presented as Mean \pm S.E.M.

RESULTS: The body weights (g) of the Zucker obese rats were greater than their agematched controls ( $523 \pm 17$ vs. $322 \pm 12)$ and their heart weights $(\mathrm{g})$ were also greater $(1.24 \pm 0.05$ vs. $1.06 \pm 0.03)$. The obese rats had higher basal systolic $\mathrm{BP}(\mathrm{mmHg})$ than the controls $(129 \pm 7$ vs. 95 \pm 8 ). 8-Br-cGMPsignificantly reduced cardiac output $(\mathrm{ml} / \mathrm{min})$ in the obese rat $(296 \pm 71$ to $168 \pm 25)$ but not in the controls $(228 \pm 41$ to $207 \pm 30)$. 8 -Br-cGMP also significantly reduced myocardial $\mathrm{VO}_{2}\left(\mathrm{ml} \mathrm{O}_{2} / \mathrm{min} / 100 \mathrm{~g}\right)$ in the obese rats $(54 \pm 9$ to $35 \pm 6)$ but not in the controls $(53 \pm 13$ to $45 \pm 7)$. There were no differences in the pattern of basal or cGMP-stimulated protein phosphorylations or total A-PDE activities between the two groups. However, addition of cGMP significantly inhibited A-PDE activities in the control rats $(-30 \pm 4 \%)$ but not in the obese rats ($15 \pm 12 \%)$.

DISCUSSION: $\quad$ The data showed that the cGMP-induced negative myocardial effects were enhanced in leptin-resistant obese rats. This could be caused by a decrease in myocardial cGMPinhibited A-PDE activities in the obese rats.

REFERENCES: $\quad$ 1. Curr Opin Nephrol Hypertens 13:215-23, 2004. 2. Am J Physiol 285: H2111-7, 2003. 